INTERNATIONAL JOURNAL OF MULTIDISCIPLINARY RESEARCH AND ANALYSis

ISSN(print): 2643-9840, ISSN(online): 2643-9875

Volume 04 Issue 07 July 2021

DOI: 10.47191/ijmra/v4-i7-19, Impact Factor: 6.072

Page No.- 1013-1022

\title{
University Branding: Student Perspectives in Private University in Indonesia
}

\author{
Totok Haryanto ${ }^{1}$, Alfalisyado ${ }^{2}$ \\ ${ }^{12}$ Economic and Business Faculty, Universitas Muhammadiyah Purwokerto, Indonesia
}

\begin{abstract}
This research aimed to identify and analyze the the phenomenon of the perspective of student towards the university branding, especially in private university in Indonesia. There are 376 students in Indonesia tested as the participant of this study. Path analysis and Sobel tests were used to test the proposed hypothesis and the intervening variable which mediate the influence of independent variable towards the dependent variable. The results of the research show that partially utilitarian value has a significant effect towards brand relationship quality, hedonic value has a significant effect towards brand relationship quality, and relational value has a significant effect towards brand relationship quality. Then in other side, the utilitarian value has a significant effect towards brand resonance, relational value has a significant effect towards brand resonance, brand relationship quality has a significant effect towards brand resonance. On contrary, brand relationship quality had no significant influence as intervening variable in mediating utilitarian value, hedonic value, and relational value towards brand resonance.
\end{abstract}

KEYWORDS: University Branding; Brand Relationship Quality; Utilitarian Value; Hedonic Value; Relational Value; Brand Resonance

\section{INTRODUCTION}

Associated with a value in college, the most important thing is the quality of the college itself. For example, from the aspect of accreditation, completeness of lecture facilities, collaboration with domestic and foreign institutions, as well as various internationalization opportunities and scholarship offers. Understanding the process of creating shared value in the type of mental stimulus from services such as higher education is very important, because its success can only be achieved through the involvement and relationships of students to participate in creating services (Waeraas \& Solbakk, 2009). According to Harvey (2018), university branding is very important, because it makes the concept of higher education more real, promising a certain quality of experience. With the right university branding campaign, it will be able to reaffirm the student/prospective student's decision to apply to the colleges that we offer.

A university must remain aware that students are advocates who create genuine value in the delivery of educational services (Robinson \& Celuch, 2016), and students play an active participatory role to interact and work collaboratively with educators (Dollinger, et.al., 2018). Fleischman, et.al. (2015) suggested that a strong brand relationship is needed by higher education institutions to increase awareness of their existence or often referred to as brand awareness. In terms of brand awareness or sensitivity to a brand (in this case the name of a college), it is closely related to how the university's efforts are in developing brand relationships with students in particular and society in general.

Various previous studies have conducted an analysis on student satisfaction and positive perceptions (Santos, et.al., 2020). In addition, a research study was also conducted by Klassen, (2002), regarding the effectiveness of university brand communication, and university branding policies (Teh \& Salleh, 2011). Universities should also be involved in branding activities that develop strong student-university identification to increase student supportive behavior towards the college where they study (Balaji, et.al., 2016).

Mitchell, et.al. (2012), that to support the discussion on the formation of customer brand relationships (CBR) in higher education services, social exchange theory suggests that brand-customer responses are driven by value exchange motivation, through psychological bonds. This is in line with the research conducted by Jayawardhena (2004), the results of which state that customer values have an indirect effect on consumer behavior through an abstract psychological mediation domain.

Based on research conducted by Kusumah, et.al. (2019), states that if there is a lack of student involvement to jointly create services, it is due to the failure of service providers to manage the formation of customer brand relationships and can lead 


\section{University Branding: Student Perspectives in Private University in Indonesia}

to unfavorable brand responses that can damage the service provider's brand image. This is also evidenced by Sternberg and Sternberg (2018), that psychological bonds are the most extensive and integrative construction in understanding human nature.

In the context of higher education institutions, Robinson and Celuch (2016), highlight that, student brand relationship quality (BRQ) resulting from strong psychological bonds leads to increased student loyalty and brand resonance (BR) responses, which can help to be key output variables. for college brands. Thomson, et al. (2005) and Whang, et.al. (2004) found that there is a significant attachment to some "objects of love", especially the emotional aspect which has basic similarities between interpersonal love in the context of human psychology. The following are indicators of brand relationship quality, namely: 1) intimacy, 2) passion, and 3) commitment.

According to Zafirovski (2005), social exchange theory highlights that the fulfillment of customer values is the main consideration for customers to stay in a relationship. Because, if there is no such thing, then there will be little motivation for the customer to continue the exchange relationship. Anand, et al. (2010) added that there are several values that can affect the psychological attachment and behavior of customers towards a brand; which are hedonic value (HV), utilitarian value (UV) and relationship value (RV).

In the context of higher education institutions, students' perceptions of value are important to the overall educational experience, and therefore it is very important for institutions to remain competitive (Verghese \& Kamalanabhan, 2015). Students will not only consider functional aspects (utilitarian value) of educational experiences and symbolic enjoyment (hedonic value), but also social aspects (relational value or relationships) that can lead to higher levels of loyalty (Gallarza, Gil-Saura, \& Holbrook, 2011). It has been shown that the inclusion of relational or relationship value, along with utilitarian value and hedonic value, significantly improves BRQ and BR predictions, thereby keeping customers in the relationship (Hashim \& Yasin, 2017).

Hirschman and Holbrook in Park (2006) stated that hedonic consumption is one aspect of customer behavior that is associated with multi-sensory, fantasy, and emotional aspects of experiences that are controlled by various benefits such as pleasure in using products or services. Indicators of hedonic value or hedonic value include: 1) brand awareness, and 2) brand meaning. (Sloot, et al., 2005). Citing from artikel Velnampy and Sivesan (2012), this study take 2 (two) main components that are used as indicators of relationship value in marketing (relational value). There are 1) trust, and 2) bonding.

Utilitarian value is a value that is considered objectively and rationally (Hanzaee, 2011). Utilitarian value is a person's motive to get prices, services and efficient use of time and energy. Cognitive evaluation uses the mind in measuring utilitarian motives (Schifman and Kanuk, 2004). The following are indicators of utilitarian value, including: 1) affordability, 2) convenience, and 3) quality. (Kusumah, 2019; Seiders, et.al., 2007).

Keller (2001) explains that brand resonance shows the natural relationship that consumers have with the brand and the degree to which consumers feel "synchronized" with the brand. Indicators in brand resonance include 1) loyalty, 2) active engagement, and 3) community sense.

Social exchange theory shows that exchange cannot be carried out without the central role of the psychological bond of customers to secure the relationship between individual values and their behavior towards objects or brands (Zafirovski, 2005). Significantly, any attempt to develop a psychological bond between the brand and the customer is likely to create a greater bond and a favorable response and brand relationship loyalty (Johnson, et.al., 2006). Coupled with aspirations, the mediating role of psychological bonds such as BRQ has received great support among marketing scholars (Ou et al. 2011). However, the evidence in the context of a university is relatively not so popular.

This study aimed to investigate the impact of the values felt by students at Indonesia (utilitarian, hedonic, and relational) on brand resonance (BR) with brand relationship quality (BRQ) as intervention variables. In addition, the mediating role of $B R$ is explored to provide a comprehensive in-depth explanation of the role of psychological bonding in shaping student and university brand relationships. In addition, this study aims to provide insight into the articulation of the formation of customer brand relationships, especially in the formation of university branding.

\section{METHODOLOGY}

The research method is a scientific way to obtain data with specific uses and purposes (Sugiyono, 2016). This research will be conducted using quantitative research methods based on the philosophy of positivism or philosophy that views the reality/symptoms/phenomena that occur. The data used in this study is primary data. The type of primary data is a data source (students) who directly provide data to data collectors, Sugiyono (2016). Then for the data collection method using an online questionnaire (with google form facilities), using a Likert scale, with a score / point of 1 (one) to 5 (five).

This research consists of 3 (three) types of variables, namely:

a) The dependent variable: brand resonance $(Y)$.

b) Independent variables, which consist of utilitarian value $(X 1)$, hedonic value $(X 2)$, and relational value $(X 3)$. 


\section{University Branding: Student Perspectives in Private University in Indonesia}

c) Intervening or mediating variables: brand relationship quality (Z).

Path analysis and Sobel tests were used to test the proposed hypothesis and to test the effect of the intervening variable in mediating the independent variable on the dependent variable. Path analysis is an extension of multiple regression analysis, or in other words path analysis is the use of regression analysis to estimate causality between variables that have been previously determined based on theory (Ghozali, 2011).

\section{RESULT AND DISCUSSION}

The data analized using multiple regression analysis and using the path analysis in testing the intervening variables. The participants of this study were 367 students from universities in Indonesia, which is shown in table 1 . The data explains about the characteristic of it's by faculty, gender, and all of them are first semester. The participant is dominated by economic and business faculty with a percentage $44,7 \%$. Then, the lowest percentage is doctor education faculty amounted $0,3 \%$.

\section{Table 1. Demography Data}

\begin{tabular}{llll}
\hline & Demographic Aspect & Amount & Percentage \\
\hline Faculty & Economic and Business & 168 & $44,7 \%$ \\
& Science and Technology & 13 & $3,5 \%$ \\
& Doctor Education & 1 & $0,3 \%$ \\
Pharmacy & 81 & $21,5 \%$ \\
Teacher and Education Science & 25 & $6,6 \%$ \\
Nursing & 54 & $14,4 \%$ \\
& Law & 2 & $0,5 \%$ \\
English Literature & 3 & $0,8 \%$ \\
& Islamic Education & 11 & $2,9 \%$ \\
Agriculture & 8 & $2,1 \%$ \\
& Psychology & 10 & $2,7 \%$ \\
\hline Sex & Male & 105 & $27,9 \%$ \\
& Female & 271 & $72,1 \%$ \\
\hline
\end{tabular}

There are three statements in measuring of the brand resonance indicator (loyalty, active engagement, and community sense). The result of the statement in brand resonance as a dependent variable are described below.

1) How about the interaction of participants who always update of information about the university.

As follow table 2 illustrated that more than half of all participants $(55,5 \%)$ agree with the statement, which means that students have up-to-date information about their university.

\section{Table 2. Loyalty Statement}

\begin{tabular}{llll}
\hline No & Response & Amount & Percentage \\
\hline 1 & Strongly agree & 90 & $23,9 \%$ \\
2 & Agree & 208 & $55,3 \%$ \\
3 & Undecided & 74 & $19,7 \%$ \\
4 & Disagree & 1 & $0,3 \%$ \\
5 & Strongly disagree & 3 & $0,8 \%$ \\
\hline Total & & $\mathbf{3 7 6}$ & $\mathbf{1 0 0 , 0 \%}$ \\
\hline
\end{tabular}

2) The participants activeness in campus activities or student activity units that they participate in university. Data shows that half of participants have the confused on their choice. It can be seen at the table 3 that $50,0 \%$ of participant picked the undecided responses. But, 31,5\% participants agree with the statement, which mean that one third of participants have the willingness in university activity. 


\section{University Branding: Student Perspectives in Private University in Indonesia}

Table 3. Active Engagement Statement

\begin{tabular}{llll}
\hline No & Response & Amount & Percentage \\
\hline 1 & Strongly agree & 34 & $9,0 \%$ \\
2 & Agree & 118 & $31,4 \%$ \\
3 & Undecided & 188 & $50,0 \%$ \\
4 & Disagree & 35 & $9,3 \%$ \\
5 & Strongly disagree & 1 & $0,3 \%$ \\
\hline Total & & $\mathbf{3 7 6}$ & $\mathbf{1 0 0 , 0 \%}$ \\
\hline
\end{tabular}

3) The participants always give recommendations to prospective students to apply for studying at the university. One third of participants $(33,0 \%)$ agree to give the advisement to potential students in order to apply for joining and studying in university. In table 4 also described that 47,6\% participant have choice the undecided criteria.

Table 4. Community Sense Statement

\begin{tabular}{llll}
\hline No & Response & Amount & Percentage \\
\hline 1 & Strongly agree & 70 & $18,6 \%$ \\
2 & Agree & 124 & $33,0 \%$ \\
3 & Undecided & 179 & $47,6 \%$ \\
4 & Disagree & 3 & $0,8 \%$ \\
5 & Strongly disagree & 0 & $0,0 \%$ \\
\hline Total & & $\mathbf{3 7 6}$ & $\mathbf{1 0 0 , 0 \%}$ \\
\hline
\end{tabular}

Illustrating the intervening variables, brand relationship quality had three indicators (intimacy, passion, and commitment) with several statements as follows.

1) Students always convey the excellence of the university at every opportunity that has to do with conversation. Based on table 5, there are $47,6 \%$ participants said agree. It had meaning that students have the tendency to insert topic about the university where they study.

Table 5. Intimacy Statement

\begin{tabular}{llll}
\hline No & Response & Amount & Percentage \\
\hline 1 & Strongly agree & 76 & $20,2 \%$ \\
2 & Agree & 179 & $47,6 \%$ \\
3 & Undecided & 118 & $31,4 \%$ \\
4 & Disagree & 3 & $0,8 \%$ \\
5 & Strongly disagree & 0 & $0,0 \%$ \\
\hline Total & $\mathbf{3 7 6}$ & $\mathbf{1 0 0 , 0 \%}$ \\
\hline
\end{tabular}

2) Students are very enthusiastic when asked to explain about the university.

In addition to undecided opinions, it turns out that from table 6 it can be seen that $38,6 \%$ of respondents agree with the statement.

Table 6. Passion Statement

\begin{tabular}{llll}
\hline No & Response & Amount & Percentage \\
\hline 1 & Strongly agree & 62 & $16,5 \%$ \\
2 & Agree & 145 & $38,6 \%$ \\
3 & Undecided & 168 & $44,7 \%$ \\
4 & Disagree & 1 & $0,3 \%$ \\
5 & Strongly disagree & 0 & $0,0 \%$ \\
\hline Total & $\mathbf{3 7 6}$ & $\mathbf{1 0 0 , 0 \%}$ \\
\hline
\end{tabular}




\section{University Branding: Student Perspectives in Private University in Indonesia}

3) Students are determined to be able to complete my studies until I graduate at university. The statement in table 7 shows that $67,0 \%$ participants strongly agree. This means that more than half of the participants are committed to completing their studies until they graduate.

Table 7. Commitment Statement

\begin{tabular}{llll}
\hline No & Response & Amount & Percentage \\
\hline 1 & Strongly agree & 252 & $67,0 \%$ \\
2 & Agree & 92 & $24,5 \%$ \\
3 & Undecided & 30 & $8,0 \%$ \\
4 & Disagree & 0 & $0,0 \%$ \\
5 & Strongly disagree & 2 & $0,5 \%$ \\
\hline Total & & $\mathbf{3 7 6}$ & $\mathbf{1 0 0 , 0 \%}$ \\
\hline
\end{tabular}

The first independent variable is the hedonic value which consist two indicators, brand awareness, and brand meaning. The three statements of the indicator can be described below.

1) Students feel happy studying at the university with the reason that the atmosphere is comfortable and impressive. The participant agreed $(50,3 \%)$ with the statement that they had the reason of their happiness because of the pleasant and magnificent of the university. The explanation can be seen at table 8 .

Table 8. Brand Awareness Statement

\begin{tabular}{llll}
\hline No & Response & Amount & Percentage \\
\hline 1 & Strongly agree & 108 & $28,7 \%$ \\
2 & Agree & 189 & $50,3 \%$ \\
3 & Undecided & 77 & $20,5 \%$ \\
4 & Disagree & 1 & $0,3 \%$ \\
5 & Strongly disagree & 1 & $0,3 \%$ \\
\hline Total & $\mathbf{3 7 6}$ & $\mathbf{1 0 0 , 0 \%}$ \\
\hline
\end{tabular}

2) The environment around the university matches with the expectations.

Table 9 describe that the $48,7 \%$ participants agree with statement about the environment surrounding university meet with their expectations.

Table 9. Brand Meaning (1) Statement

\begin{tabular}{llll}
\hline No & Response & Amount & Percentage \\
\hline 1 & Strongly agree & 87 & $23,1 \%$ \\
2 & Agree & 183 & $48,7 \%$ \\
3 & Undecided & 104 & $27,7 \%$ \\
4 & Disagree & 2 & $0,5 \%$ \\
5 & Strongly disagree & 0 & $0,0 \%$ \\
\hline Total & $\mathbf{3 7 6}$ & $\mathbf{1 0 0 , 0 \%}$ \\
\hline
\end{tabular}

3) Students feel happy studying at university because it has become their purpose.

The participants agree $(41,2 \%)$ with statement that they have the best impression when they study at the university as table 10.

Table 10. Brand Meaning (2) Statement

\begin{tabular}{llll}
\hline No & Response & Amount & Percentage \\
\hline 1 & Strongly agree & 59 & $15,7 \%$ \\
2 & Agree & 155 & $41,2 \%$
\end{tabular}


University Branding: Student Perspectives in Private University in Indonesia

\begin{tabular}{llll}
3 & Undecided & 150 & $39,9 \%$ \\
4 & Disagree & 11 & $2,9 \%$ \\
5 & Strongly disagree & 1 & $0,3 \%$ \\
\hline Total & & $\mathbf{3 7 6}$ & $\mathbf{1 0 0 , 0 \%}$ \\
\hline
\end{tabular}

The second independent variable is relational value. The variable also known as the relationship value in marketing which have two main components that are used as indicators, namely trust, and bonding. The statements are described as follow.

1) The university where the participant get learning is the place which is suitable with their expectation.

More than one third of participant chose agree, with 35,1\%. But, in table 11 shows that $46,3 \%$ students have no tendency of their option (undecided).

Table 11. Trust Statement

\begin{tabular}{llll}
\hline No & Response & Amount & Percentage \\
\hline 1 & Strongly agree & 35 & $9,3 \%$ \\
2 & Agree & 132 & $35,1 \%$ \\
3 & Undecided & 174 & $46,3 \%$ \\
4 & Disagree & 33 & $8,8 \%$ \\
5 & Strongly disagree & 2 & $0,5 \%$ \\
\hline Total & & $\mathbf{3 7 6}$ & $\mathbf{1 0 0 , 0 \%}$ \\
\hline
\end{tabular}

2) Participant have the same vission with the university.

The bonding statement at table 11 described that almost participant chosed undecided option. But, 40,4\% said agree with the statement which mean they have the same vision with university.

Table 11. Bonding Statement

\begin{tabular}{llll}
\hline No & Response & Amount & Percentage \\
\hline 1 & Strongly agree & 36 & $9,6 \%$ \\
2 & Agree & 152 & $40,4 \%$ \\
3 & Undecided & 185 & $49,2 \%$ \\
4 & Disagree & 0 & $0,0 \%$ \\
5 & Strongly disagree & 3 & $0,8 \%$ \\
\hline Total & & $\mathbf{3 7 6}$ & $\mathbf{1 0 0 , 0 \%}$ \\
\hline
\end{tabular}

The last, utilitarian value as independent variable had three indicators, namely affordability, convenience, and quality. The explanation about each statement of the indicator can be seen below.

1) The university offer the affordable tuition fees.

Although the highest percentage of options was undecided, one third of students chose to agree with the statement, with $30.3 \%$ which is illustrated in table 12 .

Table 12. Affordability Statement

\begin{tabular}{llll}
\hline No & Response & Amount & Percentage \\
\hline 1 & Strongly agree & 25 & $6,6 \%$ \\
2 & Agree & 114 & $30,3 \%$ \\
3 & Undecided & 162 & $43,1 \%$ \\
4 & Disagree & 57 & $15,2 \%$ \\
5 & Strongly disagree & 18 & $4,8 \%$ \\
\hline Total & $\mathbf{3 7 6}$ & $\mathbf{1 0 0 , 0 \%}$ \\
\hline
\end{tabular}

2) The facilities and infrastructure at the university are adequate. 


\section{University Branding: Student Perspectives in Private University in Indonesia}

Table 13 eplaine the most of student said undecide. But, 30,3\% of them picked agree with the statemen of the fulfilment of facilities and infrastructure in university.

Table 13. Convenience Statement

\begin{tabular}{llll}
\hline No & Response & Amount & Percentage \\
\hline 1 & Strongly agree & 25 & $6,6 \%$ \\
2 & Agree & 114 & $30,3 \%$ \\
3 & Undecided & 162 & $43,1 \%$ \\
4 & Disagree & 57 & $15,2 \%$ \\
5 & Strongly disagree & 18 & $4,8 \%$ \\
\hline Total & $\mathbf{3 7 6}$ & $\mathbf{1 0 0 , 0 \%}$ \\
\hline
\end{tabular}

3) The academic quality at the university is excellent.

Participants were dominated by the agree option, with a percentage of $62.5 \%$. This means that most of the participants have a good level of satisfaction with the academic quality of the university.

Table 14. Quality (1) Statement

\begin{tabular}{llll}
\hline No & Response & Amount & Percentage \\
\hline 1 & Strongly agree & 62 & $16,5 \%$ \\
2 & Agree & 235 & $62,5 \%$ \\
3 & Undecided & 78 & $20,7 \%$ \\
4 & Disagree & 1 & $0,3 \%$ \\
5 & Strongly disagree & 0 & $0,0 \%$ \\
\hline Total & & $\mathbf{3 7 6}$ & $\mathbf{1 0 0 , 0 \%}$ \\
\hline
\end{tabular}

4) The service quality at the university admissions matches with expectations.

Table 15 descibed the option which picked by participant is agree with the statement about the service quality of university admission, with a percentage $56,4 \%$.

Table 15. Quality (2) Statement

\begin{tabular}{llll}
\hline No & Response & Amount & Percentage \\
\hline 1 & Strongly agree & 66 & $17,6 \%$ \\
2 & Agree & 212 & $56,4 \%$ \\
3 & Undecided & 95 & $25,3 \%$ \\
4 & Disagree & 2 & $0,5 \%$ \\
5 & Strongly disagree & 1 & $0,3 \%$ \\
\hline Total & & $\mathbf{3 7 6}$ & $\mathbf{1 0 0 , 0 \%}$ \\
\hline
\end{tabular}

All of the result each of variable dominanted with agree options, even there are some of participant said close to agree (undecided). For more detail, as follows will describe about the interaction between independent variable to dependent variable, and also both of them related to the intervening variable.

Table 16. Model Summary

\begin{tabular}{|l|l|l|l|l|}
\hline Model & $R$ & R Square & Adjusted R Square & Std. Error of the Estimate \\
\hline 1 &, $610 a$ & 0,372 & 0,368 & 1,98569 \\
\hline
\end{tabular}




\section{University Branding: Student Perspectives in Private University in Indonesia}

Table 17. Coeficients ${ }^{a}$

\begin{tabular}{|l|l|l|l|l|l|l|}
\hline \multirow{2}{*}{ Model } & \multicolumn{2}{l|l}{ Unstandardized Coefficients } & Standardized Coefficients & \multirow{2}{*}{$\mathrm{t}$} & \multirow{2}{*}{ Sig. } \\
\cline { 3 - 7 } & B & Std. Error & Beta & & \\
\hline 1 & (Constant) & $-0,385$ & 0,816 & & $-0,472$ & 0,637 \\
\hline & X1 & 0,787 & 0,060 & 0,573 & 13,215 & 0,000 \\
\hline & X2 & 0,478 & 0,096 & 0,299 & 5,002 & 0,000 \\
\hline & X3 & 0,494 & 0,082 & 0,360 & 6,021 & 0,000 \\
\hline
\end{tabular}

a Dependent Variable: $Z$

The value of determination coeficients is 0,372 that can be seen at table 16 . This mean that brand relationship quality is influenced by independent variable (utilitarian value, hedonic value, and relational value) with a percentage $37,2 \%$. Then, each of the independent variable had less the 0,005 which mean that it had significant effect to brand relationship quality. The interaction between each variable is illustrated in figure 1.



Figure 1. The First Regression Model

Figure 1 is the first regression model of the research framework that describes the relationship between utilitarian value, hedonic value, and relational value on the brand relationship quality. From these results, the regression model can be formulated as follows.

$$
\mathrm{BRQ}=0,573 \mathrm{UV}+0,299 \mathrm{HV}+0,360 \mathrm{RV}+0,792
$$

According to data that is displayed from table 17, partially, the independent variable which are consist utilitarian value, hedonic value, and relational value had the significant influence to brand relationship quality with each value 0,000 (less than error standard 0,005). Following the independent variable and intervening variable which had effect to dependen variable can be seen from table 19. There is significant influence between utilitarian value, hedonic value, and relational value, and brand relationship quality to brand relationship resonance, respectively.

The results of SPSS application for testing the relationship between independent, dependen and intervening variable shows some interpretations as table 18 and table 19. Then, the second regression model will be explained at figure 2.

Table 18. Model Summary

\begin{tabular}{|l|l|l|l|l|}
\hline Model & $R$ & R Square & Adjusted R Square & Std. Error of the Estimate \\
\hline 1 &, $765 a$ & 0,585 & 0,583 & 1,00325 \\
\hline
\end{tabular}

Table 19. Coeficients ${ }^{a}$

\begin{tabular}{|l|l|l|l|l|l|l|}
\hline \multirow{2}{*}{ Model } & \multicolumn{2}{l|}{ Unstandardized Coefficients } & Standardized Coefficients & \multirow{2}{*}{$\mathrm{t}$} & \multirow{2}{*}{ Sig. } \\
\cline { 3 - 7 } & B & Std. Error & Beta & & \\
\hline 1 & (Constant) & 3,810 & 0,350 & & 10,885 & 0,000 \\
\hline & X1 & 0,586 & 0,033 & 0,685 & 17,783 & 0,000 \\
\hline & X2 & 0,484 & 0,034 & 0,566 & 14,264 & 0,000 \\
\hline
\end{tabular}




\section{University Branding: Student Perspectives in Private University in Indonesia}

\begin{tabular}{|l|l|l|l|l|l|}
\hline$X 3$ & 0,382 & 0,036 & 0,447 & 10,744 & 0,000 \\
\hline$Z$ & 0,259 & 0,026 & 0,416 & 10,010 & 0,000 \\
\hline
\end{tabular}

The value of determination coeficients is 0,585 that illustrated at table 18 , which mean that brand resonance is affected by utilitarian value, brand relationship quality, and relational value with a percentage $58,5 \%$. The results also show that each of variable had less the 0,005 . Its which mean that they have significant effect to brand resonance.



Figure 2. The Second Regression Model

Figure 2 is the second regression model of the research framework which illustrates the correlation between utilitarian value, hedonic value, relational value, and brand relationship quality on the brand resonance. The equation of regression model can be seen below.

$$
B R=0,685 U V+0,566 H V+0,447 R V+0,146 B R Q+0,792
$$

The following is a calculation of the direct and indirect effect of utilitarian value, hedonic value, and relational value towards brand resonance through brand relationship quality. The results show that the direct effect higher than indirect effect, with the explanation as follows:

1) The direct effect of utilitarian value to brand resonance amounted 0,685 . Then, the result of calculation of the indirect effect is $0,238(0,416 \times 0,573)$, which mean that constanta of direct effect above the indirect effect. In summary, there is no significant effect the utilitarian value towards brand resonance through brand relationship quality.

2) The direct effect of hedonic value to brand resonance amounted 0,566 . Then, the result of calculation of the indirect effect is 0,095 $(0,416 \times 0,229)$, which mean that constanta of direct effect above the indirect effect. In summary, there is no significant effect the hedonic value towards brand resonance through brand relationship quality.

3) The direct effect of relational value to brand resonance amounted 0,447 . Then, the result of calculation of the indirect effect is $0,095(0,416 \times 0,360)$, which mean that constanta of direct effect above the indirect effect. In summary, there is no significant effect the relational value towards brand resonance through brand relationship quality.

\section{CONCLUSIONS}

The utilitarian value, hedonic value, and relational value had the significant influence to brand relationship quality. This mean that quality of brand relationship can be affected by the value which is related to the student perspective. In other side, the utilitarian value, hedonic value, and relational value, and brand relationship quality, also have the significant influence to brand relationship resonance, respectively.

On contrary, brand relationship quality had no significant influence as intervening variable in mediating utilitarian value, hedonic value, and relational value towards brand resonance.

With the results that all accepted the established hypothesis, it can be seen that there is a very relevant relationship between the variables which are proxies of university branding against a private university. Thus, as a form of implication that can be followed up is by implementing several strategies that are in accordance with the indicators set out in this study.

As a suggestion for future research, a representative sample from several private universities in particular can be added. Thus, it is hoped that the results of future research will be able to represent all private university. 


\section{University Branding: Student Perspectives in Private University in Indonesia \\ REFERENCES}

1) Cicognani, E., Pirini, C., Keyes, C., Joshanloo, M., Rostami, R., \& Nosratabadi, M. 2008. Social participation, sense of community and social well-being: A study on American, Italian and Iranian university students. Social Indicators Research, Vol. 89 (1), 97-112.

2) Dollinger, M., Lodge, J., \& Coates, H. 2018. Co-creation in higher education: Towards a conceptual model. Journal of Marketing for Higher Education, Vol. 28 (2), 210-231.

3) Fleischman, D., Raciti, M., \& Lawley, M. 2015. Degrees of co-creation: an exploratory study of perceptions of international students' role in community engagement experiences. Journal of Marketing for Higher Education, Vol. 25 (1), 85-103.

4) Fullerton, G. 2005. How commitment both enables and undermines marketing relationships. European Journal of Marketing, Vol. 39 (11/12), 1372-1388.

5) Ghozali, Imam. 2016. Aplikasi Analisis Multivariete Dengan Program IBM SPSS 23 (Edisi 8). Cetakan ke VIII. Semarang: Badan Penerbit Universitas Diponegoro.

6) Keller, Kevin L. 2001. Building Customer Based Brand Equity: A Blue Print For Creating Strong Brands. Marketing Science Institute.

7) Jayawardhena, C. 2004. Personal values' influence on e-shopping attitude and behaviour. Internet Research, Vol. 14 (2), 127-138.

8) Johnson, M. D., Herrmann, A., \& Huber, F. 2006. The evolution of loyalty intentions. Journal of Marketing, Vol. 70 (2), 122132.

9) Klassen, M. L. 2002. Relationship Marketing on the Internet: The case of top-and lower-ranked US Universities and Colleges. Journal of Retailing and Consumer Services, Vol. 9 (2), 81-85.

10) Kusumah, E. P. 2019. Respon konsumen tentang kualitas pelayanan, penerimaan teknologi "tracking system" dan harga pada industri jasa pengiriman. Jurnal IImiah Bisnis dan Ekonomi Asia, Vol. 13 (2), 111-118.

11) Kusumah, E. P., Hurriyati, R., \& Dirgantari, P. D. 2019. Atribut Pemilihan Kualitas Restoran: Citra Merek dan Harga. Jurnal Bisnis dan Manajemen, Vol. 6 (2), 117-126.

12) M.S. Balaji. 2016. Antecedents and consequences of university brand identification. Journal of Business Research

13) Ou, W. M., Shih, C. M., Chen, C. Y., \& Wang, K. C. 2011. Relationships among customer loyalty programs, service quality, relationship quality and loyalty. Chinese Management Studies, Vol. 5 (2), 194-206.

14) Schiffman \& Kanuk. 2004. Perilaku Konsumen (edisi 7). Jakarta: Prentice Hall.

15) Seiders, K., Voss, G. B., Godfrey, A. L., \& Grewal, D. 2007. SERVCON: development and validation of a multidimensional service convenience scale. Journal of the Academy of Marketing Science, Vol. 35 (1), 144-156.

16) Sloot, L. M., Verhoef, P. C., \& Franses, P. H. 2005. The impact of brand equity and the hedonic level of products on consumer stock-out reactions. Journal of Retailing, 81(1), 15-34.

17) Sugiyono. 2016. Metode Penelitian Kuantitatif, Kualitatif dan Research \& Development. Bandung: PT Alfabet.

18) Teh, G. M., \& Salleh, A. H. M. 2011. Impact of brand meaning on brand equity of higher educational institutions in Malaysia. World, Vol. 3 (2), 218-228.

19) Wæraas, A., \& Solbakk, M. N. 2009. Defining the essence of a university: Lessons from higher education branding. Higher Education, Vol. 57 (4), 449. 